\title{
Problems Faced by Domestic Child Workers in Katmandu Metropolitan City, Nepal, 2006
}

\author{
Maheshor Kaphle ${ }^{1}$
}

\begin{abstract}
Children working in an employer's house with or without wages are known as domestic child workers. Domestic child workers (DCWs) are basically employed to perform domestic chores such as washing dishes, cooking, cleaning the house. Objectives: to identify the problems faced by domestic child workers. Study design and sample size: a cross-sectional study was conducted with 200 domestic child workers. Study variables: age sex reason of work, type of work, hours of work per day, monthly wages and health problems. Statistical analysis: chisquare test, z-test, ANOVA etc. result and conclusion: the study found that near about twothird of DCWs was girl. Mean age was 12.32years (SD 0.13). Main cause of migration to city from home town was to study followed by earning money. Most of them do all household work for 12 to 18 hours per day. So they did not get adequate time for rest/sleep. Majority of them did not get weekly leave. More than forty percent of DCWs were working without wages. Most of them who get wages, earn below 500 rupees (\$6.66) per month. Most of them had not formal contract and more than two-third of them not was willing to leave current work due to study purpose and not getting formal schooling as current problems. DCWs who work more hours per day get more health problems. Most of them suffered from fever headache and cold/cough. More than two third of DCWs were abused during domestic work. Most of them were scolded by their employers. To go further and want to do vocational training were their future aspiration.
\end{abstract}

\section{Introduction}

According to an international labour office (2004) report, of more than 200 million child labourers worldwide and more than 2 million children are found in domestic labour in South Africa, 559000 in Brazil, 250,000 in Haiti, 200,00 in Kenya, 264,000 in Pakistan, 100,000 in Sri Lanka, 3000,000 in Bangladesh, 62000 under the age of 14 in Nepal, and 20\% of all children under the age of 14 in India. Some 180 million are now suspected to be toiling in the worst form of child labour. Those activities that have been agreed globally to be intolerable under any circumstances and that are to be eliminated without delay [1]

Child labour use is common in Nepal. Almost one-fourth of total children of age 10-14 years are economically active. The proportion is likely to be higher as only about half of the children of this age are reported to be attending schools. Majority of children who do not attend school get involved in domestic as well as farm and other activities. In addition, the information on the economic activity of working children of age below 10 years is not available [2]. Cities in Kathmandu valley have been major migrant receiving areas. This is because, being the capital city, most of the opportunities concerning livelihood and most of the developmental infrastructures are concentrated in the Kathmandu valley city. So, the migration of children to Kathmandu valley has been created an increasing employment of children in urban areas [3].

Material and methods

Selection of children centers

\footnotetext{
${ }^{1}$ Public health department, MMIHS, Nakhu, Lalitpur.
} 
Eight non-formal education centers were established and support DCWs in 10 different school by Children and Women in Social Services and Human Right (CWISH) an NGO and 15 drop-in centre by Kathmandu metropolitan city5. Out of these education centers, $50 \%$ were randomly selected.

Selection of respondents

Individual respondents were selected by proportionate random sampling method $(50 \%$ of total respondents from each). Thus, 107 respondents were taken from drop-in canters, 28 from non-formal education centers and 65 from formal schools.

Tools and techniques

The main tool for collecting the data in this study was interview schedule. Prior to data collection, pre-testing of the schedule was done in $10 \%$ of total respondents. The data was collected through direct face to face interview with DCWs by researcher.

\section{Analysis of data}

The collected data were coded and compiled in Microsoft Excel for validation. The data was analyzed in statistical package for social sciences (SPSS. 11) software on the basic of objectives by using tools like percentage, mean, mode, range, standard deviation, z-test. ANOVA is calculated by manually. Chi-square tests were calculated in Epi-Info 2002 software.

\section{Results}

The number of girl domestic child workers was more than boys. Out of total respondents more than half of them were belongs in the 13 to 14 years age group. Girls start working at younger than boys. Mean age for boys was 12.45 and girls were 12.26 years (SD 0.13) (Table: - 1)

Table:- 1 Age and Sex wise distribution of respondents

Table:- 1 Age and Sex wise distribution of respondents

\begin{tabular}{|c|c|c|c|}
\hline \multirow{2}{*}{ Age group } & \multicolumn{2}{|c|}{ Sex } & \multirow{2}{*}{$\begin{array}{c}\text { Total } \\
\text { N (\%) }\end{array}$} \\
\cline { 2 - 3 } & $\begin{array}{c}\text { Boys } \\
\text { N (\%) }\end{array}$ & $\begin{array}{c}\text { Girls } \\
\text { N (\%) }\end{array}$ & \\
\hline 8-10 years & $9(4.5)$ & $16(8.0)$ & $25(12.5)$ \\
\hline $11-12$ years & $23(11.5)$ & $37(18.5)$ & $60(30.0)$ \\
\hline $13-14$ years & $40(20.0)$ & $75(37.5)$ & $115(57.5)$ \\
\hline Total & $\mathbf{7 2 ( 3 6 . 0 )}$ & $\mathbf{1 2 8}(\mathbf{6 4 . 0})$ & $\mathbf{2 0 0}(\mathbf{1 0 0})$ \\
\hline SE & $\mathbf{. 1 8}$ & $\mathbf{. 1 3}$ & $\mathbf{. 1 5}$ \\
\hline
\end{tabular}

Most of domestic child workers were literate but only one forth of them who just came and admit drop-in centre were illiterate. More than two-third of children had their live parents and rest were partially or total orphan $(27 \%)$. They had live parents; still they were working as domestic child worker. The reason for working was also analyzed. More than half of DCWs were migrated from other districts which are far from Kathmandu because for searching the job and for study. They could not continue their study in their village due to poverty, poor access of education and arm-conflicts (Table 2).

Table:-2 Relation between reason for migration and person for influencing to be DCWs Reason of migration Total Percentage To earn money N (\%) To study N (\%) Others* N (\%). 
Table:-2 Relation between reason for migration

\begin{tabular}{|c|c|c|c|c|c|}
\hline \multirow{2}{*}{$\begin{array}{c}\text { Influencing to be } \\
\text { DCWs }\end{array}$} & $\begin{array}{c}\text { To earn } \\
\text { money } \\
\mathbf{N}(\%)\end{array}$ & $\begin{array}{c}\text { To study } \\
\text { N (\%) }\end{array}$ & $\begin{array}{c}\text { Others* } \\
\text { N (\%) }\end{array}$ & \multirow{2}{*}{ Total } & Percentage \\
\hline Parents & $21(25.61)$ & $43(43)$ & $2(11.11)$ & 66 & 33.0 \\
\hline Relatives & $35(42.68)$ & $35(35)$ & $12(66.67)$ & 82 & 41.0 \\
\hline Villager & $13(15.85)$ & $5(5)$ & $1(5.56)$ & 19 & 9.5 \\
\hline Employer & $12(14.63)$ & $16(16)$ & $1(5.56)$ & 29 & 14.5 \\
\hline Self & $1(1.22)$ & $1(1)$ & $2(11.11)$ & 4 & 2.0 \\
\hline Total & $\mathbf{8 2 ~ ( 1 0 0 )}$ & $\mathbf{1 0 0}(\mathbf{1 0 0})$ & $\mathbf{1 8 ~ ( 1 0 0 )}$ & $\mathbf{2 0 0}$ & $\mathbf{1 0 0 . 0}$ \\
\hline
\end{tabular}

F static: Due to reason $=4.51 \mathrm{df}=2,8 \mathrm{t}=4.46$

Due to influencing persons $=4.32 \mathrm{df}=4,8 \mathrm{t}=3.84$, significant.

Out of total, majority (41\%) of them were brought them for domestic work by their relatives followed by their parents.

Out of total respondents, $40.5 \%$ did not receive any wages from their employers. More girls (42.2\%) did not receive than boys (37.5\%).this shows gender bias. Most of them (36\%) got only NRs. $<500(\$ 6.66)$ per month. The average wages was 464.28 (\$6.18) per month. Wages ranged from NRs 200 to 2000.

Most of DCWs do all household work. More than half of DCWs worked 12 to more than 16 hours per day. Average working hours per day was 12 to 16 . Health problems of DCWs were directly related to the working hours per day (table 3 ).

Table: - 3- Distribution of DCWs in working hour per day and experience of health problems (within 6 months)

Working hours per day Experience health problems N (\%) Total Percentage Health Problems No health problems.

Table: - 3- Distribution of DCWs in working hour per day

\begin{tabular}{|c|c|c|c|c|}
\hline $\begin{array}{c}\text { Working } \\
\text { hours per } \\
\text { day }\end{array}$ & \multicolumn{2}{|c|}{ Experience health problems N (\%) } & Total & Percentage \\
\cline { 2 - 3 } & Health Problems & No health problems & & \\
\hline$<8$ hours & $16(9.81)$ & $10(17.03)$ & 26 & 13.0 \\
\hline $\begin{array}{c}8 \text { to } 12 \\
\text { hours }\end{array}$ & $38(23.31)$ & $5(13.51)$ & 43 & 21.5 \\
\hline $\begin{array}{c}12 \text { to } 16 \\
\text { hours }\end{array}$ & $65(39.89)$ & $15(40.54)$ & 80 & 40.0 \\
\hline$>16$ hours & $44(26.99)$ & $7(18.92)$ & 51 & 25.5 \\
\hline Total & $\mathbf{1 6 3 ( 1 0 0 )}$ & $\mathbf{3 7}(\mathbf{1 0 0})$ & $\mathbf{2 0 0}$ & $\mathbf{1 0 0}$ \\
\hline
\end{tabular}

Out of 163 DCWs, who have suffered health problems, $40 \%$ of total respondents reported, they suffered from fever and headache followed by cold and cough. Care during illness was also analyzed. A majority (67.5\%) of DCWs was cared by employer but less percentages (74 
$\%)$ of girls were cared by employer as compared to boys (96.72\%). Treatment practice was not so good majority of employers did not take their DCWs to hospital when they got ill. Only $30.88 \%$ of DCWs were taken hospital by their employer. DCWs were given medicine from pharmacy. Out of 92 DCWs who were injured during domestic work, $43.4 \%$ of them reported they experienced cut (hand) followed by $25 \%$ both cuts and burns during domestic work. Out of total respondents, $70 \%$ were not willing to leave job, reason was asked, they had no other job (30.7\%) and nearly $24 \%$ of the children were not willing as they were getting support for their study and another $30 \%$ were waiting to get opportunity for study.

More than two third of DCWs were scolded or beaten or any types of abuse. This table shows that $68.5 \%$ DCWs were facing any abuse or violence. Types of violence were also analyzed. Almost $93 \%$ of domestic child workers were scolded by their employers, but less number of girls was slapping (14.4\%) as compared to boys (25\%). Percentage of severe beating is comparatively less $(8 \%)$.

Table: - 4- Prevalence of Violence among Domestic Workers Children.

\begin{tabular}{|l|l|l|l|}
\hline \multirow{2}{*}{$\begin{array}{l}\text { Prevalence of } \\
\text { violence }\end{array}$} & \multicolumn{2}{|c|}{ Sex } & \multirow{2}{*}{ Total (\%) } \\
\cline { 2 - 3 } & Boys (\%) & Girs (\%) & \\
\hline Violence present & $46(63.9)$ & $91(71.0)$ & $137(68.5)$ \\
\hline Violence absent & $26(36.1)$ & $37(29.0)$ & $63(31.5)$ \\
\hline Total & $\mathbf{1 0 0 ( 1 0 0 . 0 )}$ & $\mathbf{1 2 8 ( 1 0 0 . 0 )}$ & $\mathbf{2 0 0 ( 1 0 0 . 0 )}$ \\
\hline
\end{tabular}

Cal. $X^{2}=1.11$, tab. value $=3.841, p=0.292$, Non-significant

\section{Conclusion}

Most of children were becoming domestic child workers due to poor access of education and poverty. Parents and relatives influenced for being DCWs. Most of them were working all household work in very low wages. The common diseases, they suffered were fever/headache and cold/cough. The occurrence of disease was closely related to working hours. They did not get adequate time for study, play and rest or sleep. More than two-third of DCWs were abused during domestic work. Most of them were scolded by their employers.

\section{Recommendations}

Children are made domestic child workers to fulfill their aspiration of study and earning and are facing many health and social problems. Income generation activities should be laid down in poor community and the parents should be taught about child rights, so they should not force their child to be domestic worker for earning money. Child education should be free and compulsory. School education program should be implemented and strengthened in the risk community and also support the parents for education of their child such as fee, books, stationary, scholarships, uniforms etc.

\section{References}

1) Bharati P. An overview of Domestic Workers in Asia. ILO Geneva; 2002.

2) Pradhan YB \& Hamal PK. A Survey Study on Migrant Working Children in Kathmandu valley; An unpublished report submitted in CWIN; Nepal; 1998.

3) UNICEF. Situation analysis of child labour in Nepal; A synopsis; Nepal; UNICEF; 1997.

4) Child workers in Nepal concerned center (CWIN) misery behind the looms: child labour in Kathmandu Nepal. Kathmandu: CWIN-Nepal; 1993.

5) Children-women in social services and human right (CWISH).children domestic service in Kathmandu valley. Annual status report (CWISH); 2004. 